\title{
Current Evidence of Mesenchymal Stem Cells Use in the Treatment of Tendon Disorders: A Systematic Review, Meta-analysis, and Meta-regression of Prospective Clinical Studies
}

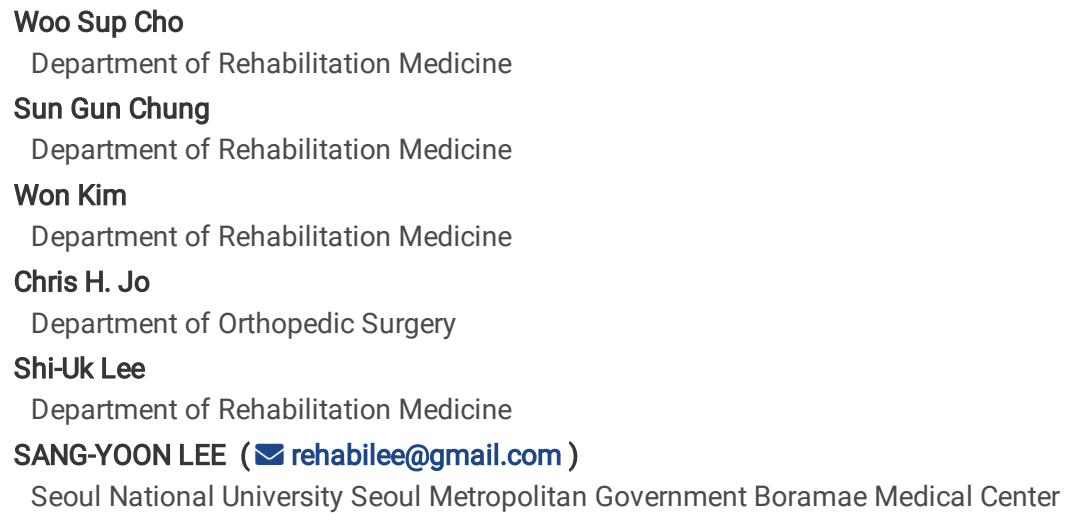




\section{Abstract}

Purpose: Although several studies with animals have reported the effects of mesenchymal stem cells (MSCs) for tendon regeneration, little is known about the efficacy and safety of MSCs in human tendon disorders. We performed this meta-analysis to evaluate the efficacy and safety of MSC therapy in patients with tendon disorders enrolled in prospective clinical studies.

Methods: We systematically searched prospective clinical studies investigating the effects of MSCs administration on human tendon disorders with at least a 6-month follow-up period on PubMed-Medline, Embase, and Cochrane Library databases. The primary outcome of interest was the change in pain on motion related to tendon disorders. We performed a pairwise meta-analysis using the fixed-effects model to assess treatment response, which was calculated by the standardized mean difference. Meta-regression analyses were performed to assess the relationship between MSCs dose and pooled effect sizes in each cell dose.

Results: Four prospective clinical trials investigating the effect of MSCs on tendon disorders were retrieved. MSCs showed significant pooled effect size (overall Hedge's g pooled standardized mean difference $(S M D)=1.868 ; 95 \%$ confidence interval $[\mathrm{Cl}], 1.274-2.462 ; \mathrm{P}<0.001$ ). The treatment with $\mathrm{MSCs}$ improved all the aspects analyzed, i.e. pain, functional scores, radiologic parameters (magnetic resonance image or ultrasonography), and arthroscopic findings. In the meta-regression analysis, there was a significant cell dose-dependent response in pain relief $(Q=9.06, P=0.029)$. While three studies reported mild adverse events after MSCs injection, these were not severe and relieved spontaneously.

Conclusions: Our meta-analysis revealed that MSC therapy may improve pain, function, radiologic, and arthroscopic parameters in patients with tendon disorders. Due to the small number of studies in this meta-analysis and considering the increasing MSCs applications, there is a strong need for large-scale randomized controlled trials to confirm the long-term functional improvement as well as the adverse effects of MSC therapies in tendon disorders.

\section{Background}

Mesenchymal stem cells (MSCs) treatment is a new regenerative therapy for treating tendon disorder. Preclinical studies have reported that MSC therapy may increase the number of tenocytes and regenerate the injured tendon tissue [1-4]. While several studies with animals support the treatment of tendon disorders using MSCs, little is known about the efficacy and safety of MSCs to treat these conditions in humans. Although a few clinical reports suggested the therapeutic potentials of MSCs in tendon disorders, they are mostly case reports or case series. Only one randomized controlled trial reported preliminary results (EudraCT Number: 2007-007630-19), but there are no published results yet [5].

A systematic review of MSC therapy on tendon disorder [6] analyzed three case series [7-9] and one matched non-randomized trial [10]. They concluded that MSC treatment is not yet suitable for clinical practice, because the included studies are at high risk of bias. However, the result should be reconsidered, since three $[7,8,10]$ of the four studies included in this review were not performed with isolated MSCs but bone marrow aspirates or stromal vascular fractions cells. Moreover, this study was not carried out with the meta-analysis methodology, which combines the results from multiple studies. Furthermore, two current clinical studies $[5,11]$, which used isolated MSCs on tendon disorder, were not included in the review.

Although there is an increasing number of published research on stem cell treatments, there are no meta-analyses on this topic to date. Furthermore, concerns regarding possible adverse events of MSC treatments, raised by physicians or scientists reluctant to the therapy [12], should be thoroughly reviewed. Thus, we performed an updated meta-analysis of prospective clinical studies in order to evaluate the efficacy and safety of MSC therapies in patients with tendon disorder.

\section{Methods}

\section{Search Strategy}

The meta-analysis was conducted according to the updated guidelines of the Preferred Reporting Items for Systematic review and Meta-Analysis Protocols (PRISMA-P) [13]. Searches on PubMed-Medline, Embase, and Cochrane Library were performed in February 2019 using the following key terms and syntax: (Tendinopathy OR Tendon OR Tendon disorder OR Tendon injuries OR Tendinosis OR Tendinitis OR Tennis elbow OR Elbow Tendinopathy OR Lateral epicondylitis OR Lateral epicondylosis OR Golfer's elbow OR Rotator cuff OR Rotator Cuff Injuries OR De Quervain disease OR Jumper's knee OR Achilles tendon) AND (Stem cells OR Mesenchymal stem cells OR Progenitor cells OR Mother cells OR Multipotent OR Pluripotent OR Totipotent) AND Clinical studies [14, 15]. An overview of the search strategy is presented in Supplementary Appendix A. We included all prospective clinical studies investigating the effects of MSCs administration on tendon disorder. We imposed no language restriction. We also searched for unpublished and grey literature using the following databases and trial registries: World Health Organization Clinical Trial Register, EU clinical trials register, ClinicalTrials.gov, and OpenGrey.

\section{Study Selection Criteria}

Identified records were saved to the EndNote software (X7.2; Thomson Reuters). Two independent reviewers (WSC and SYL) screened all the titles and abstracts to identify relevant investigations. The inclusion criteria were as follows: (1) articles reporting a prospective clinical study with at least a 6-month follow-up that (2) described the effect of MSC therapy in patients with any tendon disorder. Although there were no limitations in types of MSCs, i.e. cell origin; autologous or allogeneic, we excluded studies which did not use isolated MSCs, e.g. bone marrow aspirates or stromal vascular fractions cells. Reviews, basic science articles, comments, letters, and protocols were excluded. When updates of earlier studies were available, we used only the most recent ones. 


\section{Outcome Measures and Data Extraction}

The primary outcome of interest was defined as pain on motion related to tendon disorder. All types of pain measurements, e.g. visual analog scale or numeric rating scale, were included. The secondary outcomes analyzed in this study were as follows: 1) functional scores of joint, such as the Constant score, the UCLA score, the modified Mayo elbow performance index, or the Shoulder Pain and Disability Index; 2) radiological parameters to measure tendon defects using magnetic resonance image or ultrasonography; and 3) arthroscopic findings to measure tendon defects with a calibrated arthroscopic probe. For every eligible study, the following data were extracted and entered into a spreadsheet by the two reviewers (WSC and SYL): first author's family name, year of publication, study design, types of tendon disorder, origin of the MSCs, number of patients, MSCs injection methods, cell doses, follow-up duration, safety assessment, and efficacy measurements. We assessed publication bias using Begg's funnel plot [16] and Egger's test [17].

\section{Statistical Analysis}

Effect sizes were computed as standardized mean difference (SMD) measures,[18] representing the magnitude of the pretest-posttest difference for each outcome. SMD was calculated separately for all the available control and treatment groups for each study. Heterogeneity between comparable studies was tested with the chi-squared $\left(\mathrm{X}^{2}\right)$ and $\mathrm{I}^{2}$ tests. Values of $\mathrm{P}>0.1$ and $\mathrm{I}^{2}<50 \%$ were considered statistically significant. Because there was no significant heterogeneity among the four studies $\left(P=0.658\right.$ and $\mathrm{I}^{2}=0.0 \%$ ), we used a fixed-effects meta-analysis to quantify the pooled effect size of the studies included. In each analysis by outcome, the following parameters: pain $\left(P=0.093\right.$ and $\left.\mathrm{I}^{2}=47.0 \%\right)$, functional scores $\left(P=0.313\right.$ and $\left.\mathrm{I}^{2}=15.3 \%\right)$, radiological parameters $\left(P=0.406\right.$ and $\left.\mathrm{I}^{2}=0.0 \%\right)$, and arthroscopic findings $\left(P=0.588\right.$ and $\left.\mathrm{I}^{2}=0.0 \%\right)$ were also analyzed using the fixed-effects model. Additionally, we performed a meta-regression analysis to assess the relationship between MSCs dose and pooled effect sizes in each cell dose. All analyses were performed using the Comprehensive Meta-Analysis Software (version 3.3; Biostat, Englewood, NJ, USA). This study was exempted from Institutional Review Board review as no human subjects were involved.

\section{Results}

\section{Description of Included Studies}

The primary database search yielded 1,135 records. After duplicates were removed, the titles and abstracts of 897 articles were initially screened and 25 selected for full-text review. The full-text articles were read and 4 were considered relevant by qualitative analysis $[5,9,11,19]$. The studies selected for final inclusion or exclusion are shown in Fig. 1, and the characteristics of the included studies are summarized in Table 1. In terms of quantitative analysis, these four studies (published from 2015 to 2018) fulfilled our inclusion criteria. Three papers $[9,11,19]$ were open-label prospective studies, while one [5] was an unpublished double-blind randomized controlled trial. The studies identified for meta-analysis included 52 participants. Two studies $[9,19]$ employed adipose tissue-derived MSCs and the other two $[5,11]$ administered bone marrow-derived MSCs. The number of cells used in each study ranges from $10^{6}$ to a maximum of $10^{8}$. Regarding tendon disorder types, most of the studies were performed on rotator cuff tear, but one study [9] was conducted on lateral epicondylitis. The follow-up duration ranged from 6 to 12 months.

Table 1. Characteristics of the Individual Studies Included

\begin{tabular}{|c|c|c|c|c|c|c|c|c|c|c|c|c|}
\hline \multirow[t]{2}{*}{ Study } & \multirow[t]{2}{*}{ Region } & \multirow[t]{2}{*}{$\begin{array}{l}\text { Study } \\
\text { period }\end{array}$} & \multirow[t]{2}{*}{$\begin{array}{l}\text { Study } \\
\text { design }\end{array}$} & \multirow[t]{2}{*}{$\mathbf{N}$} & \multirow{2}{*}{$\begin{array}{l}\text { Tendon } \\
\text { disorder }\end{array}$} & \multirow{2}{*}{$\begin{array}{l}\text { MSC } \\
\text { origin } \\
\text { (type) }\end{array}$} & \multirow[t]{2}{*}{ Injection method } & \multirow{2}{*}{$\begin{array}{l}\text { MSC } \\
\text { dose } \\
\text { (cells) }\end{array}$} & \multirow[t]{2}{*}{$\begin{array}{c}\text { F/U } \\
\text { period }\end{array}$} & \multirow[t]{2}{*}{ Safety } & \multicolumn{2}{|c|}{ Efficacy } \\
\hline & & & & & & & & & & & Primary & Secondary \\
\hline $\begin{array}{l}\text { Jo } \\
2018\end{array}$ & $\begin{array}{l}\text { South } \\
\text { Korea }\end{array}$ & $\begin{array}{l}\text { Jul } \\
2015- \\
\text { Nov } \\
2016\end{array}$ & $\begin{array}{l}\text { Open-label, } \\
\text { dose- } \\
\text { escalation } \\
\text { trial }\end{array}$ & 19 & $\begin{array}{l}\text { Partial- } \\
\text { thickness } \\
\text { rotator cuff } \\
\text { tear }\end{array}$ & $\begin{array}{l}\text { Autologous } \\
\text { adipose } \\
\text { tissue- } \\
\text { derived } \\
\text { MSCs }\end{array}$ & $\begin{array}{l}\text { Intratendinous injection } \\
\text { under the US guidance, } \\
\text { MSCs in } 3 \mathrm{ml} \text { of saline }\end{array}$ & $\begin{array}{l}1.0 \times \\
10^{7} \\
5.0 \times \\
10^{7} \\
1.0^{7} \times \\
10^{8}\end{array}$ & $6 \mathrm{mo}$ & $\begin{array}{l}\text { NCI-CTCAE V } \\
4.0\end{array}$ & SPADI & $\begin{array}{l}\text { Constant } \\
\text { score, pain } \\
\text { (VAS) } \\
\text { shoulder } \\
\text { MRI (tendon } \\
\text { defects), } \\
\text { arthroscopy }\end{array}$ \\
\hline $\begin{array}{l}\text { Lee } \\
2015\end{array}$ & $\begin{array}{l}\text { South } \\
\text { Korea }\end{array}$ & $\begin{array}{l}\text { May } \\
2013- \\
\text { Sep } \\
2014\end{array}$ & $\begin{array}{l}\text { Open-label, } \\
\text { conventional } \\
3+3 \text { cohort } \\
\text { expansion } \\
\text { design }\end{array}$ & 12 & $\begin{array}{l}\text { Lateral } \\
\text { epicondylitis }\end{array}$ & $\begin{array}{l}\text { Allogeneic } \\
\text { adipose } \\
\text { tissue-- } \\
\text { derived } \\
\text { MSCs }\end{array}$ & $\begin{array}{l}\text { Intratendinous injection } \\
\text { under the US guidance, } \\
\text { MSCs with fibrin glue } \\
\text { (total volume of } 1 \mathrm{ml} \text { ) }\end{array}$ & $\begin{array}{l}1.0 \times \\
10^{6} \\
1.0^{\prime} \times \\
10^{7}\end{array}$ & $12 \mathrm{mo}$ & $\begin{array}{l}\text { Local/systemic } \\
\text { tolerances, US } \\
\text { exam }\end{array}$ & $\begin{array}{l}\text { Pain } \\
\text { (VAS) }\end{array}$ & $\begin{array}{l}\text { Modified } \\
\text { mayo elbow } \\
\text { performance } \\
\text { index, elbow } \\
\text { US (tendon } \\
\text { defects) }\end{array}$ \\
\hline $\begin{array}{l}\text { Havlas } \\
2015\end{array}$ & $\begin{array}{l}\text { Czech } \\
\text { Republic }\end{array}$ & $\begin{array}{l}\text { Oct } \\
2012\end{array}$ & $\begin{array}{l}\text { Prospective } \\
\text { study with } \\
\text { consecutive } \\
\text { participants }\end{array}$ & 8 & $\begin{array}{l}\text { Rotator cuff } \\
\text { tear }\end{array}$ & $\begin{array}{l}\text { Autologous } \\
\text { bone } \\
\text { marrow- } \\
\text { derived } \\
\text { MSCs }\end{array}$ & $\begin{array}{l}\text { Arthroscopic repair and } \\
\text { suspension of MSCs to } \\
\text { the suture site }\end{array}$ & $\begin{array}{l}1.0 \pm \\
0.45 \times \\
10^{7}\end{array}$ & $6 \mathrm{mo}$ & $\begin{array}{l}\text { Local and } \\
\text { systematic } \\
\text { adverse } \\
\text { reactions (not } \\
\text { clearly } \\
\text { described) }\end{array}$ & $\begin{array}{l}\text { Pain } \\
\text { (VAS) }\end{array}$ & $\begin{array}{l}\text { Constant } \\
\text { score, UCLA } \\
\text { score }\end{array}$ \\
\hline $\begin{array}{l}\text { Lamas } \\
2015\end{array}$ & Spain & $\begin{array}{l}\text { Apr } \\
2010\end{array}$ & $\begin{array}{l}\text { Double-blind } \\
\text { randomized } \\
\text { controlled } \\
\text { trial }\end{array}$ & 13 & $\begin{array}{l}\text { Full- } \\
\text { thickness } \\
\text { rotator cuff } \\
\text { tear }\end{array}$ & $\begin{array}{l}\text { Autologous } \\
\text { bone } \\
\text { marrow- } \\
\text { derived } \\
\text { MSCs }\end{array}$ & $\begin{array}{l}\text { Surgical repair with } \\
\text { Attached with } \\
\text { OrthADAPT }^{\mathrm{TM}} \text { membrane }\end{array}$ & $\begin{array}{l}2.0 \times \\
10^{7}\end{array}$ & $12 \mathrm{mo}$ & $\begin{array}{l}\text { Examined but } \\
\text { not mentioned }\end{array}$ & $\begin{array}{l}\text { Constant } \\
\text { score }\end{array}$ & $\begin{array}{l}\text { Tendon } \\
\text { status by } \\
\text { MRI } \\
\text { Pain (VAS) }\end{array}$ \\
\hline
\end{tabular}

Abbreviations: MSCs, Mesenchymal Stem Cells; US, Ultrasonography; NCI-CTCAE, National Cancer Institute-Common Terminology Criteria for Adverse Events; SPADI, Shoulder Pain and Disability Index; VAS, Visual Analog Scale; MRI, Magnetic Resonance Imaging; UCLA, University of California at Los Angeles. 
The MSC therapies showed a significant pooled effect size (overall Hedge's g pooled SMD = 1.868; 95\% confidence interval [Cl], 1.274-2.462; $\mathrm{P}<0.001$ ) (Fig. 2). The parameters of pain, functional scores, radiological parameters (magnetic resonance image or ultrasonography), and arthroscopic findings all improved with MSC treatment (Fig. 3). In the meta-regression analysis, there was a significant cell dose-dependent responses in pain relief $(\mathrm{Q}=9.06, \mathrm{P}=$ 0.029) (Fig. 4). While three studies reported mild adverse events after MSCs injection, these were not severe and relieved spontaneously (Table 2). Publication bias was not evident, as shown by the symmetrical Begg's funnel plot (Supplementary Appendix B), and the P-value for bias was 0.625 (Egger's test; all four trials).

Table 2. Adverse Events Reported in Individual Studies Included

\begin{tabular}{|c|c|c|c|c|c|}
\hline Study & Adverse events & $\mathbf{N}$ & Treatment & Prognosis & Treatment-related \\
\hline \multirow[t]{5}{*}{ Jo 2018} & Back pain & 3 & Rescue drug, physical therapy & Recovered & No \\
\hline & Right foot bruise, left trigger finger & 1 & Rescue drug, physical therapy & Recovered & No \\
\hline & Cough & 1 & Medication & Recovered & No \\
\hline & Left eye pain & 1 & Eye drop & Recovered & No \\
\hline & Abdominal pain & 1 & Medication & Recovered & No \\
\hline \multirow[t]{3}{*}{ Lee 2015} & Mild regional swelling & 6 & Observation & Recovered & Yes \\
\hline & Mild elbow joint effusion & 2 & Observation & Recovered & Yes \\
\hline & Delayed elbow pain & 1 & Rescue drug & Recovered & No \\
\hline Lamas 2015 & Swelling, pain, reduced range of motion (chronic synovitis) & 4 & Surgery (remove the patch) & Recovered & Yes \\
\hline
\end{tabular}

\section{Discussion}

Potential evidence has shown that the MSCs injection improves pain, joint functions, radiological, and arthroscopic parameters in patients with tendon disorder. Although all included studies had a small sample size, the results clearly presented MSCs dose-dependent responses regarding pain relief. To the best of our knowledge, this is the first clinical meta-analysis describing the pooled effects of MSC therapies on patients with tendon disorder.

Tendon injuries are a common health problem, which are defined as a painful condition occurring around tendons that limits the function of the affected tendons [20]. Tendons are susceptible to repeated use or degenerative condition. Injuries in those structures are rarely regenerated but repaired by scar tissue and fibrosis. This healed tissue presents inferior tensile strength and is prone to further injuries. Preclinical studies support that MSCs have a regenerative potential as those cells are able to differentiate into proper tendon cell and elicit the secretion of cytokines or growth factors [1]. Therefore, MSCs have been regarded as a possible curative treatment option for tendon degeneration.

Implanted stem cells survive in tendon defects, differentiate into the tenogenic cell lineage and secrete their own extracellular matrix to promote tendon healing [4]. Mazzocca et al. showed that bone marrow-derived stem cells differentiate into tendon-like cells [21]. Lee et al. also reported that transplanted human adipose tissue-derived stem cells survived for at least 4 weeks in the rat tendon injury model and released human-specific collagen type I and tenascin-C $(\mathrm{TnC})[4]$. The expression of $\mathrm{TnC}$ is known to increase rapidly during the early period of recovery after tendon injuries, and thus may be used as a marker of tenogenic differentiation [22].

In this meta-analysis, three of the four included studies examined radiological data (magnetic resonance image or ultrasonography) or arthroscopic findings after MSCs injections. These tests could confirm that the injected cells not only relieved pain and improved functions but also regenerated the damaged tissue. Noteworthy, Jo et al conducted the second-look arthroscopic examination at 6 months following MSCs injection as well as MRI follow-up [19]. They reported that the regenerated tendon tissues were identified in all subjects regardless of the location and size of the tear. The defect volumes were decreased in the groups that received mid-dose $\left(5.0 \times 10^{7}\right.$ cells $)$ and high-dose $\left(1.0 \times 10^{8}\right.$ cells $)$. Although this is a macroscopic observation, it may be strong supporting evidence for the regeneration effect of MSCs.

Another important biological mechanism supporting MSC therapy is paracrine effect exerted by these cells [1]. Kinnaird et al. found that growth of endothelial cells and smooth muscle cells may be promoted by the use of medium conditioned with MSCs. This phenomenon might be partly explained by the presence of VEGF and bFGF, which appeared in high levels in the MSCs conditioned medium [23]. The ability of the MSCs to produce a wide range of immunomodulatory and trophic factors has also attracted great attention [24].

There are several concerns regarding the use of MSCs as a treatment option for tendon disorder. Particularly, potential long-term adverse events from the stem cell treatment have been poorly reported in several clinical studies. In the studies included in this meta-analysis, most of the reported adverse events were not related to treatment (Table 2). The treatment-related side effects were regional swelling following allogeneic stem cell injection [9] or engrafted patch-related chronic synovitis [5]. The joint swelling spontaneously subsided, while the patch-related adverse event needed additional surgery. Considering the prognosis of the reported adverse events, these side effects might have come from the localized inflammatory response related to the treatment procedure, or to immunologic response against allogeneic cells.

The safety issues related to the MSCs have already been sufficiently assessed in clinical trials in the field of internal medicine, in which MSCs are injected systemically. The POSEIDON trial [25] was designed to investigate the safety and efficacy of autologous and allogeneic MSC therapies for ischemic 
cardiomyopathy. The study reported that, following trans-endocardial stem cell injection, the treated group showed improvement in structural and functional outcomes, while no serious adverse events including immunologic reactions occurred. Indeed, long-term adverse events from the stem cell treatment and its possible teratogenicity should be thoroughly considered. One animal study reported undesired cartilage formation after the injection of human MSC in eighty-one rat tendon injury models [26]. While there was no histologic evidence of tumor formation in the study, concerns for possible teratogenicity still remain.

Although there are numerous challenges to be overcome and analyzed, it is undisputable that MSC therapy is a potential treatment option to treat tendon disorder. In particular, about $17 \%$ of patients with tendon disorder are known to have no effects after undergoing conservative treatment for more than one year [27]. In some patients, the rate of re-tear is fairly high, even following surgical repair for tendon injuries [19]. Thus, the limitations of the current therapies suggest a need for more fundamental regenerative treatments and MSCs might offer the regenerating opportunity for the tendon by yielding a more robust repair tissue [28]. In order for MSCs injections to be established in tendon disorder, the aforementioned long-term safety issues should be better verified. Furthermore, well-designed clinical trials should be performed in order to support the evidence.

There are several limitations to this meta-analysis. First, we employed a limited number of studies included in our meta-analysis. Moreover, there was only one randomized controlled study available, which has not been published yet. Since MSCs have been applied for the treatment of tendon disorder for only a short period of time, the number of studies that fulfilled our criteria was limited. If a sufficient number of studies had been analyzed, more solid evidence could have been obtained. However, it is meaningful to combine the data through the meta-analysis because there are not enough studies related. Second, included studies were heterogeneous in many ways. Two studies were performed with the administration of bone marrow-derived MSCs, while the other two studies used adipose tissue-derived MSCs. The specific disease entities presented in the studies were also different, namely three studies aimed at treating the rotator cuff disease and one, lateral epicondylitis. However, in order to assure that the mechanisms and efficacy of MSC therapies in tendon disorder are clear and evident, it will be necessary to evaluate whether these treatments are suitable for not just a single specific tendinopathy but for multiple pathologies, which may involve various musculoskeletal structure.

\section{Conclusions}

Our meta-analysis revealed that MSC therapy may improve pain, function, and radiological and arthroscopic parameters in patients with tendon disorder. Due to the limited sample size in this meta-analysis and considering the increasing MSCs applications, there is a strong need for large-scale randomized controlled trials to confirm the long-term functional improvement and adverse effects of MSC therapies in tendon disorder.

\section{List Of Abbreviations}

MRI: magnetic resonance image; MSCs: mesenchymal stem cells; PRISMA-P: Preferred Reporting Items for Systematic review and Meta-Analysis Protocols; SMD: standardized mean difference; $\mathrm{TnC}$ : tenascin-C

\section{Declarations}

Ethics approval and consent to participate: Not applicable

Consent for publication: Not applicable

Availability of data and materials

All data generated or analysed during this study are included in this published article and its supplementary information files.

Competing interests: The authors declare that they have no competing interests.

Funding: None.

Authors' contributions

WSC, SGC and SYL designed the study. WSC and SYL collected the data. WK and SYL conducted the data analysis. CHJ, SUL and SYL interpreted results and drafted the manuscript. All authors read and approved the final manuscript.

\section{Acknowledgements: None.}

\section{References}

1. Young M. Stem cell applications in tendon disorders: a clinical perspective. Stem Cells Int. 2012;2012:637836.

2. Barboni B, Russo V, Gatta V, et al. Therapeutic potential of hAECs for early Achilles tendon defect repair through regeneration. Journal of Tissue Engineering and Regenerative Medicine. 2018;12:e1594-e1608.

3. Liao GP, Choi Y, Vojnits K, et al. Tissue Engineering to Repair Diaphragmatic Defect in a Rat Model. Stem Cells International. $2017 ; 2017$.

4. Lee SY, Kwon B, Lee K, et al. Therapeutic Mechanisms of Human Adipose-Derived Mesenchymal Stem Cells in a Rat Tendon Injury Model. Am J Sports Med. 2017;45:1429-1439.

Page 5/9 
5. Lamas JR, Tornero-Esteban P, Fernández CG, et al. A Double-Blind, Randomized, Placebo-Controlled Trial of Mesenchymal Stem Cells for the Treatment of Patients with Full-Thickness Rotator Cuff Tears. 2015 ACR/ARHP Annual Meeting. 2015.

6. Pas $\mathrm{H}$, Moen $\mathrm{MH}$, Haisma $\mathrm{HJ}$, et al. No evidence for the use of stem cell therapy for tendon disorders: a systematic review. Br J Sports Med. 2017;51:996-1002.

7. Pascual-Garrido C, Rolon A, Makino A. Treatment of chronic patellar tendinopathy with autologous bone marrow stem cells: a 5-year-followup. Stem Cells Int. 2012;2012:953510.

8. Ellera Gomes JL, da Silva RC, Silla LM, et al. Conventional rotator cuff repair complemented by the aid of mononuclear autologous stem cells. Knee Surg Sports Traumatol Arthrosc. 2012;20:373-377.

9. Lee SY, Kim W, Lim C, et al. Treatment of Lateral Epicondylosis by Using Allogeneic Adipose-Derived Mesenchymal Stem Cells: A Pilot Study. Stem Cells. 2015;33:2995-3005.

10. Hernigou P, Flouzat Lachaniette $\mathrm{CH}$, Delambre J, et al. Biologic augmentation of rotator cuff repair with mesenchymal stem cells during arthroscopy improves healing and prevents further tears: a case-controlled study. Int Orthop. 2014;38:1811-1818.

11. Havlas V, Kotaska J, Konicek P, et al. [Use of cultured human autologous bone marrow stem cells in repair of a rotator cuff tear: preliminary results of a safety study]. Acta Chir Orthop Traumatol Cech. 2015;82:229-234.

12. Wohn DY. Korea okays stem cell therapies despite limited peer-reviewed data. Nat Med. 2012;18:329.

13. Preferred reporting items for systematic review and meta-analysis protocols (PRISMA-P) 2015: elaboration and explanation. BMJ (Clinical research ed.). 2016;354:i4086.

14. Tsikopoulos K, Tsikopoulos I, Simeonidis E, et al. The clinical impact of platelet-rich plasma on tendinopathy compared to placebo or dry needling injections: A meta-analysis. Phys Ther Sport. 2016;17:87-94.

15. Ranger TA, Wong AM, Cook JL, et al. Is there an association between tendinopathy and diabetes mellitus? A systematic review with meta-analysis. Br $\mathrm{J}$ Sports Med. 2016;50:982-989.

16. Begg CB, Mazumdar M. Operating characteristics of a rank correlation test for publication bias. Biometrics. 1994;50:1088-1101.

17. Egger M, Davey Smith G, Schneider M, et al. Bias in meta-analysis detected by a simple, graphical test. BMJ. 1997;315:629-634.

18. Becker BJ. Synthesizing standardized mean-change measures. British Journal of Mathematical and Statistical Psychology. 1988;41:257-278.

19. Jo $\mathrm{CH}$, Chai JW, Jeong EC, et al. Intratendinous Injection of Autologous Adipose Tissue-Derived Mesenchymal Stem Cells for the Treatment of Rotator Cuff Disease: A First-In-Human Trial. Stem Cells. 2018;36:1441-1450.

20. Andres BM, Murrell GA. Treatment of tendinopathy: what works, what does not, and what is on the horizon. Clin Orthop Relat Res. 2008;466:1539-1554.

21. Mazzocca AD, McCarthy MB, Chowaniec DM, et al. Rapid isolation of human stem cells (connective tissue progenitor cells) from the proximal humerus during arthroscopic rotator cuff surgery. Am J Sports Med. 2010;38:1438-1447.

22. Nemoto M, Kizaki K, Yamamoto Y, et al. Tenascin-C Expression in Equine Tendon-derived Cells During Proliferation and Migration. J Equine Sci. 2013;24:17-24.

23. Kinnaird T, Stabile E, Burnett MS, et al. Local delivery of marrow-derived stromal cells augments collateral perfusion through paracrine mechanisms. Circulation. 2004;109:1543-1549.

24. Liang X, Ding Y, Zhang Y, et al. Paracrine mechanisms of mesenchymal stem cell-based therapy: current status and perspectives. Cell Transplant. 2014;23:1045-1059.

25. Hare JM, Fishman JE, Gerstenblith G, et al. Comparison of allogeneic vs autologous bone marrow-derived mesenchymal stem cells delivered by transendocardial injection in patients with ischemic cardiomyopathy: the POSEIDON randomized trial. JAMA. 2012;308:2369-2379.

26. Machova Urdzikova L, Sedlacek R, Suchy T, et al. Human multipotent mesenchymal stem cells improve healing after collagenase tendon injury in the rat. Biomed Eng Online. 2014;13:42.

27. Coombes BK, Bisset L, Vicenzino B. Efficacy and safety of corticosteroid injections and other injections for management of tendinopathy: a systematic review of randomised controlled trials. Lancet. 2010;376:1751-1767.

28. Carballo CB, Lebaschi A, Rodeo SA. Cell-based approaches for augmentation of tendon repair. Tech Shoulder Elb Surg. 2017;18:e6-e14.

\section{Figures}



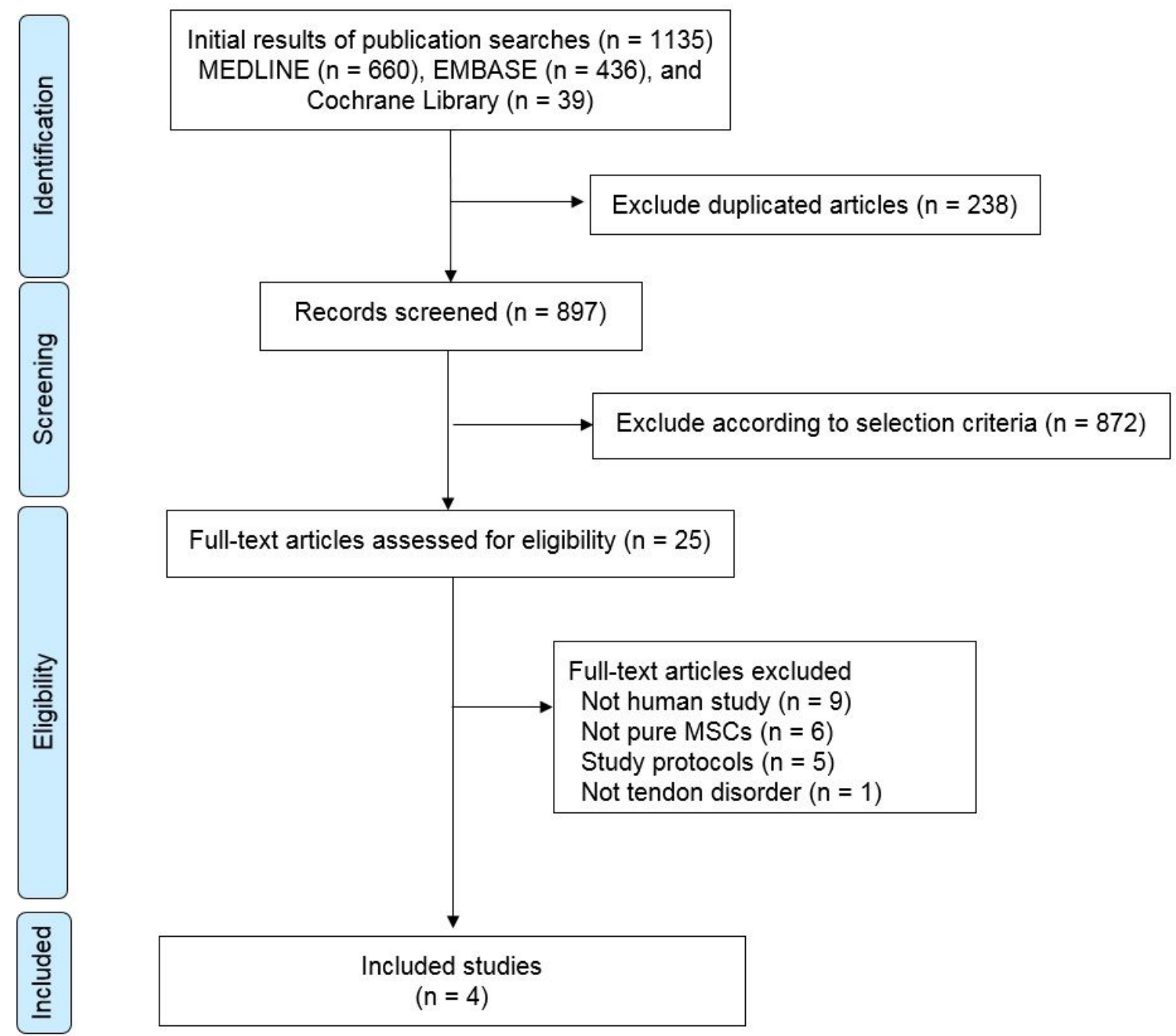

Figure 1

Preferred Reporting Items for Systematic review and Meta-Analysis flow diagram detailing the selection process of relevant clinical studies.

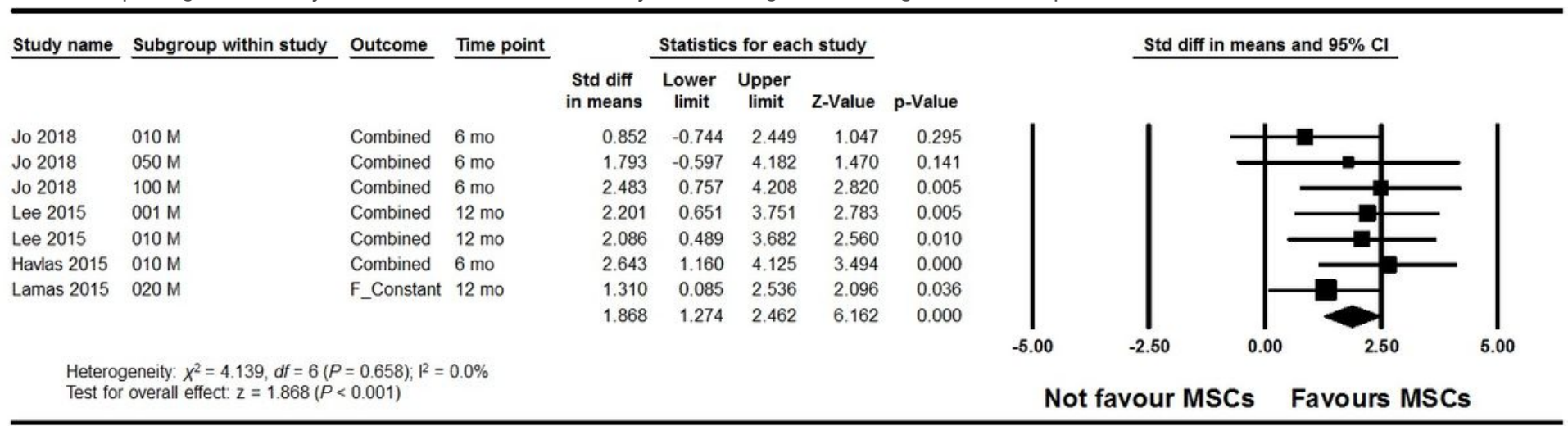

Figure 2

Forest plot of the pooled effect of MSCs on tendon disorders determined by a fixed-effects meta-analysis. Effect sizes are indicated as Hedges' $\mathrm{g}$ standardized mean differences and $95 \%$ confidence intervals. 


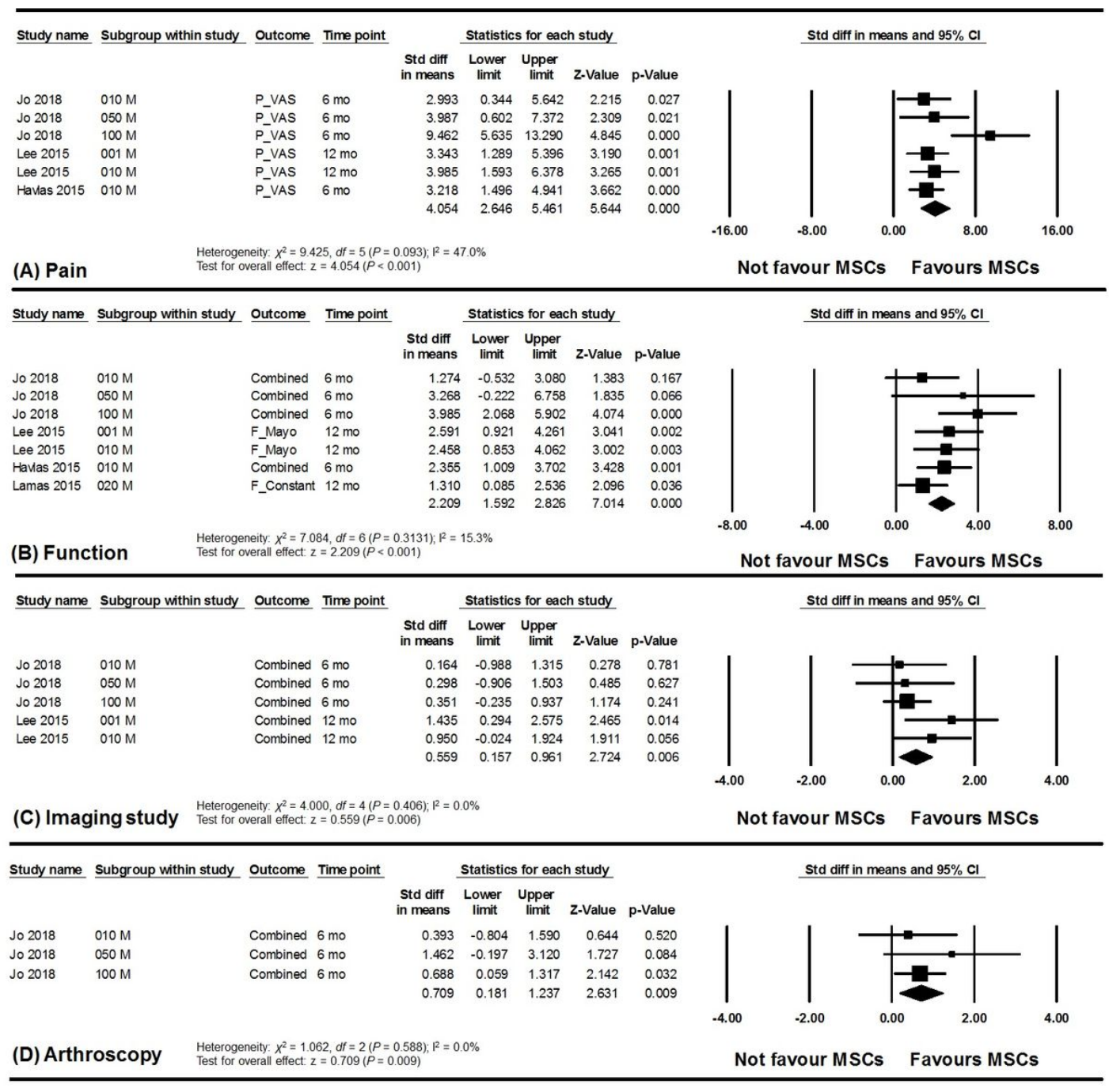

Figure 3

Forest plots of the effects of trial/cell dose-level characteristics of MSCs analyzed as outcome variables: (A) pain (primary outcome), (B) functional scores, (C) radiologic parameters, and (D) arthroscopic findings. 


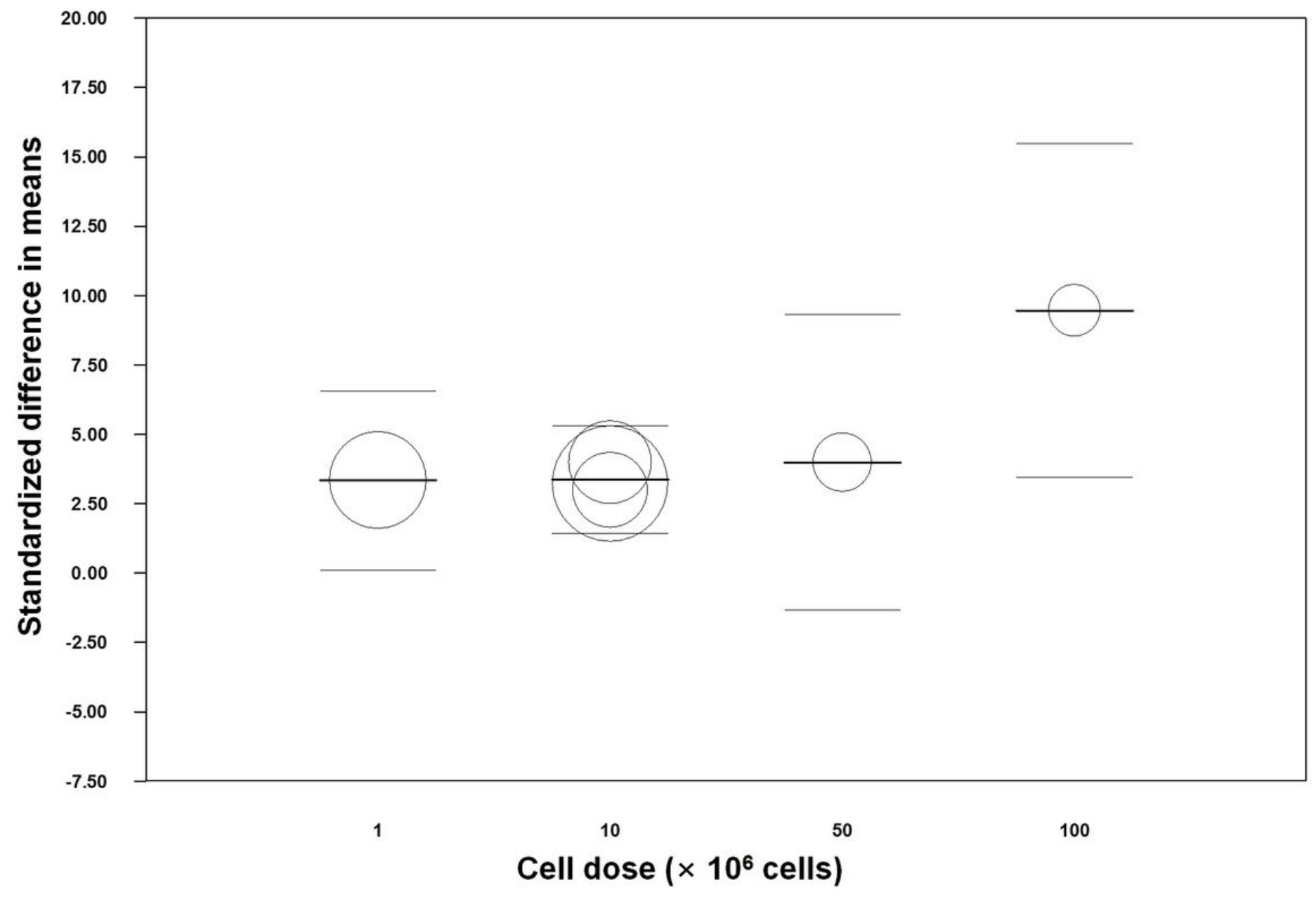

Figure 4

Meta-regression of the standardized mean differences in means for cell dose. The area of the circles is proportional to the studies' weights in the regression.

\section{Supplementary Files}

This is a list of supplementary files associated with this preprint. Click to download.

- AppendixAQuery.docx

- AppendixB.Funnelplot.tif 